\title{
Politics, Religion, and Society: Is the United States Experiencing a Period of Religious-Political Polarization?
}

\author{
Thomas A. Hirschl ${ }^{1}$, James G. Booth ${ }^{2}$, Leland L. Glenna ${ }^{3}$ \& Brandn Q. Green ${ }^{4}$ \\ ${ }^{1}$ Department of Development Sociology, Cornell University, NY, USA \\ ${ }^{2}$ Department of Biological Statistics and Computational Biology, Cornell University, NY, USA \\ ${ }^{3}$ Department of Agricultural Economics, Sociology, and Education, Pennsylvania State University, Pennsylvania, \\ USA \\ ${ }^{4}$ Environmental Center, Bucknell University, Pennsylvania, USA \\ Correspondence: Th omas A. Hi rschl, Department of D evelopment So ciology, Aca demic Sur ge A, C ornell \\ University, Ithaca, NY 14853, USA. Tel: 1-607-255-1688. E-mail: tah4@cornell.edu
}

Received: June 6, 2012 Accepted: July 10, 2012 Online Published: August 3, 2012

doi:10.5539/res.v4n4p95

U RL: http://dx.doi.org/10.5539/res.v4n4p95

\begin{abstract}
This study investig ates the effect of religious id entity on U.S. Presi dential voter choice in order to determine whether th is relationship chan ged over time. Th e research literature i s divided on $t$ his question with sev eral investigators finding a positive trend in religious-political $\mathrm{p}$ olarization sin ce 1980 , and others fi nding no polarization. The stud y further addresses a pu tative li nk between so cial in equality and relig ious politics by identifying the race, $\mathrm{cl}$ ass, and ge nder location of religiously influenced voters, using multiple cross sections from the General S ocial Survey to em pirically model P residential voting over the period 1980 to 2008 . The findings demonstrate th at religious id entity in fluenced voter cho ice, and $t$ hat th is influ ence in creased significantly and substantially across the study period. Second, that upper class whites are the source of religious partisan polarity, and upper class whites beca me more polarized over the period 1980 to 2008. The effect of gender on partisanship is less p ronounced, and overshadowed by social class and religious identity. The study findings demonstrate that religiously influenced Presidential voting reflects the political behavior of a relatively privileged component of the electorate.
\end{abstract}

Keywords: religious id entity, politics, so cial stratification, id eology, race, class, gender, US presid ential voter choice

\section{Introduction}

Social science research indicates that religious identity is a driv er of political behavior within the United States. This finding is broadly confirmed, for example in empirical investigations of Presidential voter choice conducted since World War II (Converse, 1964; Greeley \& Hout, 2006; Knoke, 1974; Manza \& Brooks, 1997; Regenerus, Sikkink, \& Smith , 199 9; Sh erkat \& Ellison, 199 9). Th ere are $m$ ultiple in terpretations of th is empirical relationship, perhaps because it is no tobvio us why, or how, vo ter cho ice is su bject to religious identity, the former defined by the here and now, the latter b y the hereafter (Billings \& Sco tt, 1994; Woodberry \& Smith, 1998). It is also the case that prominent European founders of social science predicted the demise of religion in favor of secular worldviews. Because comparative analysis indicates that religious beliefs and practices are more pervasive within the United States relative to most European nations (Inglehart \& Baker, 2000), it is tempting to view Weber's (2 004) a nd Durkheim's (2 001) p redictions of secularization as a p roduct of $t$ heir Eu ropean experience. At least for the case of U.S. Presidential voter choice, the influence of religious identity appears not to have diminished.

In this study we in vestigate the trend line in the affect of religious identity on U.S. Presidential voter choice in order to determine whether this relationship has, in fact, changed over time. The research literature is divided on this qu estion with sev eral investigators finding a po sitive tren $\mathrm{d}$ in rel igious-political p olarization sin ce 1980 (Gelman, Park, Shor, \& Cortina, 2010; Fiorina, Abrams, \& Pope, 2011:134; Layman, 2001; 1997), and others finding no po larization (Brooks \& Man za, 20 04; Man za \& Broo ks, 1997). Th is task is both em pirical an d interpretive because an empirical trend is unimportant in the absence of substantive interpretation. However in 
fashioning an interpretation we are confronted by difficulties related to the broad import of a research question that touches upon several areas of social science inquiry including political science, political sociology, religious studies, the sociology of religion, and social stratification. The latter is pertinent because the period in question is defined by widening economic in equality, hence a co mputed trend line should allow for economic differences, given that these differences were changing across the study period. Research that spans multiple areas of social science inqui ry is dem anding because eac $\mathrm{h}$ area has its own preference set rega rding resea rch procedures, including differing approaches to measuring religious identity.

This st udy builds upon a model proposed by Hirschl, B ooth, \& Gl enna (2009) (HBG) that defines rel igious identity effects on voter choice as contingent upon the individual's location within the stratification order. In this model the empirical link between religious identity and voter choice is allowed to $\mathrm{v}$ ary independently by race, class, and gender. We view this as an appropriate framework, given the economic inequality trend mentioned in the prior $\mathrm{p}$ aragraph, and the lik elihood that in dividuals in different po sitions in th e stratificatio $\mathrm{n}$ order are exposed to differential economic change that could, at least potentially, influence voter choice. In this study the HBG model is tested in two new dimensions. First, the model's proposed measure of relig ious identity is tested for validity acro ss three ind ependent surv eys. Th is was done because we are skeptical of the HBG measure, namely that it may lack a val id axis of interpretation among voters. Second, we extend the time horizon of the HBG model to facilitate a test for ch ange over time. The present study comprises the 1980 to 2008 Presidential elections, and in cludes a test for time trends; the HBG analysis covered the 1980 to 2000 Presidential elections, and did not test for change over time.

\subsection{Economic Inequality, Religion and Politics since 1970}

If one reviews U.S. inequality indicators over the past four decades, it is appare nt that inequality increases are substantial and sustained. The Gini coefficient of income inequality increased approximately 25 percent between 1970 and 2010, from .35 to .44 (U.S. Census Bureau, 2011). The national income share of the top ten percent of families increased from 33 percent in 1972 to 50 percent in 2007 (Atkinson, Piketty, \& Saez, 2011). And the national share of financial wealth owned by the richest 20 percent of families re mained high, increasing slightly from 91 percent in 1983 to 93 percent in 2007 (Wolff, 2010). These trend lines were unanticipated by many social scien tists, who since Kuznets (1955), exp ected that in equality wo uld decrease, or rem ain stable, within highly developed countries such as the United States.

Various attempts have been made to link religiously influenced political activity to the failure of so cial policy and po litics to redu ce econ omic in equality. For ex ample in an an alysis of econo mic in equality sin ce 1960 , Hacker \& Pierso n (2010:179) argue th at "the rise of Christian con servatism" partially explains the ab sence of pro-equality political response to economic inequality; however, these authors present no empirical evidence in support of th is claim. Ad ditionally there is a $\mathrm{p}$ opular notion that middle and working class support for social equality has been attenuated by a political focus on non-economic "culture-war" issues, such as prayer in public schools and leg alized abo rtion (Frank, 2004). However, in an an alysis of the 1984 to $2004 \mathrm{~N}$ ational Election Study of Presidential Elections, Bartels (2005) found evidence that the middle and working classes continue to support social equality, defined as government spending, government jobs, and aid for minorities. Likewise the notion that American s are en gaged in a "culture war" (Hu nter, 1991) pitting secu larists an d relig ious lib erals against religious trad itionalists $\mathrm{h}$ as $\mathrm{b}$ een judged to be lack ing in em pirical sp ecificity and validity (W illiams, 1997).

Because religious identity has bee $\mathrm{n}$ shown to have robust affects on voter choice, a focus on this relationship offers a m easurable way to calib rate the relation of religion to politics. On e way to proceed is not to ask if religious voting is obscuring economic inequality, blocking pro-equality politics, or contributing to a culture war, but rath er $\mathrm{to}$ examine its $\mathrm{d}$ istribution across th e stratif ication ord er. Is relig iously in fluenced voting $\mathrm{m}$ ore prominent within the upper classes, or with in the lower classes, and how is this distribution changing over time? The stratificati on lo cation of relig iously influ enced vo ters b egins to define the con text fo $r$ questions ab out religion and economic inequality. If the poorest, least affluent voters are also the strongest religious voters, then this lends credence to the interpretation that economic inequality losers are interpreting their political options in religious terms. If, on the other hand, the mo st privileged voters are disproportionately the stron gest relig ious voters, then this suggests something quite different, that the relativ ely privileged interpret their political options in religious terms. To identify these empirical relationships we measure religious identity effects on voter choice, and com pare the de nsity of this dist ribution acro ss differing lo cations with in th e stratificatio $\mathrm{n}$ order. We additionally measu re trend 1 ines i $\mathrm{n}$ hese differences: are th ese differences in creasing, $\mathrm{d}$ ecreasing, o $\mathrm{r}$ ot changing? These elem ents $d$ efine th e emp irical lin kage $b$ etween voter ch oice, reli gious i dentity, and th e stratification order. 
Measures of s ocial class al one are insufficient indicat ors of $t$ he stratification order because of $t$ he connection between race and class established by U.S. history. In addition, the intersection of race, religion, and voter choice presents a puzzle that is of interest to researchers (Greeley \& Hout, 2006: 72). We also include gender because it has been shown to be a critical dimension of the stratification order. Thus we endeavor to link religious identify effects on voter choice to position within the stratification order, defined by race, class, and gender.

\section{Current Knowledge about Religious Identity Effects on Voter Choice}

There are $t$ wo so cial scien ce th eories linkin g voter ch oice to relig ious id entity: eth noreligious th eory, and religious restructuring theory. Ethno religious theory postulates a set of link ages between relig ious trad itions, ethnicity, and partisan politics th at develop acro ss ti me (Jensen, 1971; Kleppner, 1979). Althou gh research ers acknowledge that net partisan choice varies marginally from el ection to el ection, the un derlying linkages a re theorized to remain in tact. In th is ap proach cau sality is em pirically located at the level of church m embership defined by ethnic and religious traditions that cau sally link to voter choice. Manza \& Broo ks $(1997,2004)$ are exemplars of ethnoreligious theory, and deploy empirical variants using the National Election Study within two analyses of Presidential voter choice, one for elections spanning 1960 to 1992, and another for the 1972 to 2000 elections. In bo th an alyses they fo und high, but relativ ely stab le lev els of relig ious cleav age, confirming the ethnoreligious proposition regarding civil so ciety linkages between religious traditions and partisan politics. In particular they found little pa rtisan change a mong Cath olics, Jews or conservative ("ev angelical") Pro testants. Their analysis i dentifies $\mathrm{m}$ oderate partisan $\mathrm{c}$ hange a mong " $\mathrm{m}$ ainline P rotestants," $\mathrm{w}$ ho $\mathrm{m}$ oved from $\mathrm{t}$ he Republican to the Democratic Party. Thu s to the extent religious-political polarization was found during these two tim e $\mathrm{p}$ eriods, it was i $\mathrm{n}$ th e opposite direction perceived $\mathrm{b}$ y $\mathrm{m}$ any $\mathrm{p}$ olitical analysts an $\mathrm{d}$ pun dits who characterize religious political change in term s of conservative Protestants leaving the Democratic Party for the Republican Party (Philips, 2006).

The alternative theoretical model is religious restructuring theory that operates at the level of individual belief, and presumes that major religious traditions/denominations are sp lit between individuals adhering to traditional religious authority, versus individuals adhering to relatively secular, or "progressive" authority (Wuthnow, 1988; Hunter, 1997). In a st udy of Pr esidential vo ter cho ice over the period 1980 to 1994, also using the $\mathrm{N}$ ational Election Stud y, Lay man (1997) fou nd in creasing religious-political p olarization using two v ariables d erived from relig ious restru cturing th eory: "d octrinal orthodoxy" and " religious $\mathrm{c}$ ommitment." Laym an m easures doctrinal orthodoxy with a scale co mbining responses to questions about being "born again" with responses to a biblical aut hority quest ion; religious c ommitment is const ructed from que stions ab out frequency of $\mathrm{c}$ hurch attendance, and from responses to questions about religious salience. Over the study period the effect of these two constructs on voter choice increased, and the implication is that, over time, rel igiously influenced voters became more likely to vote Republican, whe reas $\mathrm{m}$ ore sec ular i ndividuals became $\mathrm{m}$ ore likely to vot e Democratic. Consistent with Manza and Brooks (1997, 2004), Layman found no change over time with regard to the affect of religious tradition on voter choice. Comparing the Layman results to the Manza and Brooks results suggests th at th $\mathrm{e} t$ wo theories of relig ion an d politics id entify different tren ds an $d$ relationships in religious voting.

A study by Fiorina, Abrams, \& Pope (2011) confirms a po lar connection between religion, measured as church attendance, and voter cho ice b etween 1992 and 200 4, using th e National Election Stu dy. Ov er this period individuals $\mathrm{f}$ requently at tending $\mathrm{c}$ hurch became st ronger $\mathrm{R}$ epublican $\mathrm{v}$ oters, an $\mathrm{d}$ i ndividuals $\mathrm{w}$ ho attended infrequently, or not at all, became stronger Democratic voters. In interpreting their study results, Fiorina, Abrams, and Pope cite a related an alysis by Bo lce \& DeMaio (1999) of a National El ection Pilot St udy that re ports polarization b etween Christian fu ndamentalists and secu lar voters, sp ecifically th at "neg ative feelings toward Christian fundamentalists are a si gnificant predictor of relative party assessment" (ibid:508). To the extent this study has validity, it suggests that religious polarization is gaining traction within the political sphere.

Gelman et al. (201 0) identify a nu ance to the Fiorina, Abrams, \& Pope (2011) study utilizing a v ariety of data sources including the National El ection St udy, two National Annenberg El ection surveys, and a C ooperative Congressional Election Study. Gelm an et al. find evi dence that partisan re ligious pola rity characterizes upper income Presi dential vot ers, where high-income churc $\mathrm{h}$ attenders a re strong $\mathrm{R}$ epublican pa rtisans, vers us high-income, non-attending voters that are strong Democratic partisans. Low-income voters, conversely, are not split by religious observance. Gelman et al. correlate th is finding to the "red state/blue state" dichotomy where the former are characterized by church-going economic elites, and the latter by secular elites.

Some researchers rea son that the two the ories describe different aspects of the same process, and c ombine the two theories to ach ieve a m ore comprehensive an alysis. For ex ample, Guth, Kellstedt, Smidt, \& Gr een (2006) 
blend ethn oreligious theory and restructuring th eory in an an alysis of the 2004 Presidential Election, creati ng hybrid em pirical measures of relig ious identity. Gu th et al.'s (2006) an alysis is b ased on a national su rvey of 4,000 respondents, in terviewed before and after the 2004 election, and the an alysis found that vo ter cho ice is predicted by hybrid cat egories derived from both theories. Thus for example, there is a voter choice g radient across "trad itional," "cen trist," an d "modernist" ind ividuals with in the "mainline Protestant" trad ition, an d th is gradient has a si milar sl ope, $b$ ut different $m$ ean 1 evels, wi thin $t$ he more $\mathrm{R}$ epublican-leaning "e vangelical Protestant" tradition (Guth et al., 2006: 228). These results are consistent with the proposition that ethnoreligious theory and restructuring theory predict voter choice using different domains of religiosity.

Hirschl, Boo th \& G lenna (20 09) (H BG) propose a m odel that com bines ele ments from both the ories. Their model is ak in to religious restructuring theory insofar as it emphasizes biblical authority as a key component of religious identity. The emphasis is justified with reference to the Christian Bible's visibility within religious and secular s pheres of American society, e.g. i ts functi on in legal and ci vic ri tuals (K ramnick \& M oore, 2 005). Second, th eir model of religio us i dentity im plies th at th e $\mathrm{m}$ eaning of biblical au thority $\mathrm{v}$ aries $\mathrm{b}$ y religious tradition, in particular between Catholics and Protestants that have differing institutional and historical legacies with regard to rel igious authority (R iesebrodt, 1993; Weber, 1958). Thus HBG de ploy the va riable "religious tradition" in combination with biblical authority.

The HBG empirical approach is inductive st atistical modeling where voter choice is an unrestrained function of biblical au thority, relig ious tradition, an d stratificatio n categories; in clusion of the stratificatio n categ ories is further justified with reference to Durkheim (Hirschl, Booth, \& Glenna, 2009: 929). Because Durkheim proposes that relig ious sen timents a nd rituals orig inate with in $\mathrm{t}$ he real $\mathrm{m}$ of $\mathrm{t}$ he i ndividual's material and $\mathrm{m}$ ental dependency up on so ciety, relig ious categories nece ssarily bear som e re lationship t o ec onomic and s ocial categories. In practice this theory can be operationalized to the extent that a common symbolic system operates across secular and sacred spheres, and hence the HBG model depends upon a common axis of perception about biblical authority. For this reason we first assess the character of social interpretation of biblical authority before proceeding to analyze trends in the affect of religious identity on voter choice.

\section{Data and Methods}

This study reports analysis of three surveys. First, the General Social Survey (GSS) is a nationally representative, repeat cro ss-section sam ple of the Eng lish sp eaking, non-in stitutional po pulation ag e 18 and ov er. The GSS component of the study analyzes voter ch oice for ei ght Presidential el ections 1980 to 2008 , and the dat a are derived from 20 annual or biannual surveys comprising 11,411 non-Hispanic white respondents, and 1,870 black respondents with complete sets of independent and dependent variables.

Second, the 2009 Cornell National Social Survey (CNSS) is a ra ndom sample of 1,000 households within the United States. One household member age 18 years of age and older is interviewed. The survey contains questions about Presidential voter choice in 2008, and repeats GSS survey questions used to construct the independent and dependent variables in the GSS analysis. In add ition, it includes a new biblical authority scale designed by the study a uthors. Third, st udents taking "Introduction to S ociology" at Cornell U niversity were su rveyed during spring, 2010, in order to validate the biblical authority scale from the 2009 CNSS.

The dependent variable for the GSS/CNSS analyses is the binary voting preference for the Republican versus Democratic Presidential candidate. We exclude nonvoters and third party candidates from the analysis in order to focus upon can didate cho ice for the two maj or political parties. Other variables on the right hand side include relative family income used to proxy the individual's social class. Although income is not the favored approach for measuring social class, it is widely acknowledged to be implicated in class position (Domhoff, 2002; Perrucci \& Wysong, 2008; Wright, 1996). We reco de total family in come in to quartiles where quartile 4 is the top 25 percent, and roughly corresponds to Perrucci and Wysong's "comfort class." In 2005 dollars, the lower boundary for the top family income quartile is $\$ 75,000$ per annum, and the upper boundary is top-coded at $\$ 150,000$. The first family in come quartile boundaries are zero to $\$ 22,499 \mathrm{per}$ an num, second quartile bo undaries $\$ 22,500$ to $\$ 39,999$, and third quartile boundaries $\$ 40,000$ to $\$ 74,499$.

Other variables in the analysis are gender, Southern region defined as categories 5-7 (South Atlantic, East South Central and West South Cent ral) for the GSS variable, REGION, and race (white versus black). In the GSS, blacks are the sole minority group sufficiently large for multivariate statistical analysis.

The GSS/CNSS independent variable "religious identity" is operationalized by cross-classifying two measures: biblical au thority an $\mathrm{d}$ reli gious trad ition. Bib lical authority is o perationalized by th e an swer to th is multiple-choice question in the GSS (Davis, Smith, \& Marsden, 2005: 197): 
1. Which of these statements comes closest to describing your feelings about the Bible?

a. The Bible is the actual word of God and is to be taken literally, word for word.

b. The Bible is the inspired word of God but not everything in it should be taken literally, word for word.

c. The Bible is an ancient book of fables, legends, history, and moral precepts recorded by men.

It is not necessary that the respondent actually read the Bible, or has direct textual knowledge of it. Rather, the variable measures whether the individual possesses "feelings" that the Bible is the literal word of God, versus the inspired word of God, or a book of fables. From the perspective Durkheim's (2001) theory of religion and society, responses "a" and "b" can be understood as communal projections of authority onto an object, in this case the Christian Bible. Becau se the Bible functions within secular as well as sacred spheres of American society, its authority is not limited to the sacred, and $b$ iblical litera lism in $\mathrm{p}$ articular has been found to be a sym bolic resource for political mobilization (Riesebrodt, 2005).

The G SS/CNSS m easure of rel igious $t$ radition is de rived from the GSS question, "What is y our rel igious preference?" (Davis, Smith, \& Mar sden, 2005: 169), and is use d to cre ate a va riable that corres ponds to the major two rel igious trad itions in American so ciety: Protestan ts, $d$ ivided $b$ etween $t$ he larg est $d$ enomination Baptist an d other Pro testant, Cath olic, v ersus all o ther relig ious trad itions and non-religious in dividuals. We tested our emp irical $\mathrm{m}$ odels with $\mathrm{v}$ arious sch emes fo $\mathrm{r}$ classifyin $\mathrm{g}$ relig ious trad ition, in cluding "mainline Protestant," and "evangelical Protestant," (Steensland et al., 2000), and fo und no sub stantive differences in the final results.

In addition to the GSS biblical authority question, participants in the CNSS were asked whether they agreed (yes or no) with the following four statements about the Bible:

2. The Bible should help guide political decisions.

3. The Bible is to be read literally.

4. The Bible is without contradiction.

5. The Bible is an authoritative document which has moral rules I must follow.

Thus, the CNSS data c ontains five cat egorical res ponses rel ating to re spondents' views of biblical authority. These questions rep resent an attempt to reco ver information on the link b etween biblical au thority, cognition, and behavior that is more encompassing than GSS Question 1.

As a v alidation ex periment we ask ed students in "In troduction to So ciology" at Corn ell University du ring the spring of 2010 to rate each of the responses to Question 1 and Statements 2-5, concerning biblical authority (11 responses int otal). The stud ents were ask ed to use a 5-point Likert scale with 1 re presenting a res ponse indicating t he res pondent i s a " non-Christian/atheist/religious cy nic," an d 5 i ndicating a $\mathrm{n}$ "ev angelical Christian/biblical literalist" respondent.

\subsection{Analysis of Biblical Belief}

In order to assess the dimensionality and structure of the CNSS biblical belief responses, we en tered the CNSS data in to a M ultiple Co rrespondence Analysis (MCA) (Greenacre \& Blasius, 200 6). Mu ltiple co rrespondence analysis (MCA) can be thought of as the analog of principle components analysis for categorical variables. The multiple correspondence map is a plot of the responses on the first two principle dimensions, computed from the data structure. This map is given in Figure 1 for the responses to the question, and statements, concerning views about the Bible. The map suggests an ordering of the responses on a 1-dimensional continuous scale, namely the $1^{\text {st }}$ principle coordinate. Thus, for example, responses "a" and "c" to Question 1 are, respectively, at the positive and negative extremes, while response "b" is in the middle of the scale. A "no" response to Statement 5 is close to the response "c" for Que stion 1 at the negative end of the scale. On the other hand a "yes" response to Statement 5 is in the positive part of the scale, but some distance from the positive extreme. 


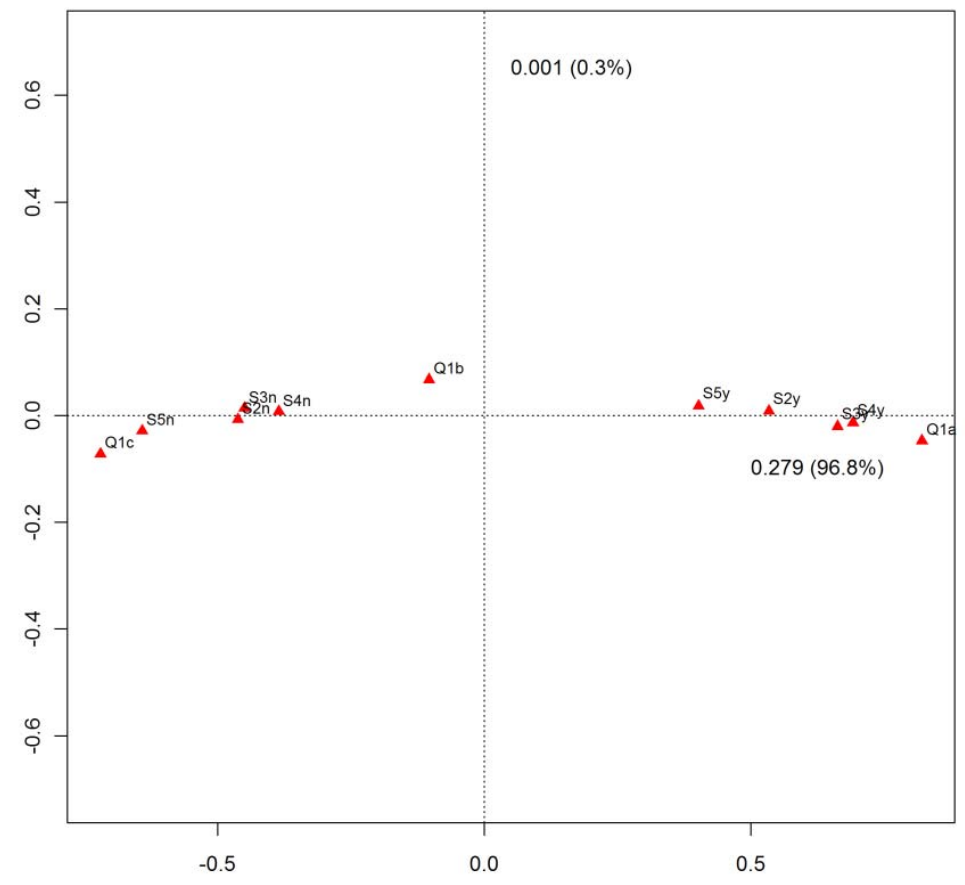

Figure 1. Multiple correspondence map of responses to question and statements concerning biblical authority: data labels correspond to responses to biblical authority question 1, and statements 2 - 5, e.g., S5.n denotes a "no" response to statement 5 , etc. The first principle coordinate explains $96.8 \%$ of inertia

The results in Figure 1 can be compared to the average ratings given by Cornell students to the eleven responses. Table 1 shows how the st udents rated the eleven biblical belief res ponses, sorted acc ording to ave rage Likert score. ${ }^{1}$ This ordering is the same as that based on the MCA $1^{\text {st }}$ principle coordinate with the exception that the order of responses 4.y and 3.y are s witched. However, the scores for these two res ponses are almost identical both in the CNSS d ata and in the stud ent survey. In fact, the spacing of the scores fro $m$ the two datasets is remarkably similar. The main difference is that the students rate respon se " $b$ " to question 1 closer to the higher (biblical literalist) end of the scale.

Table 1. R espondent rat ings of biblical aut hority q uestion 1 a nd st atements 2- 5, 108 st udents e nrolled i n introductory sociology, Cornell University, fall, 2009*

\begin{tabular}{lccccccccccc}
\hline Response & Q1.c & S5.n S2. & n S3. & n S4. & n & Q1.b & S5.y S2.y & S4.y & S3.y & Q1.a \\
\hline $\begin{array}{l}\text { Average } \\
\text { Score }\end{array}$ & 1.371. & 481. & 701. & 962. & 343. & 564. & 414. & 514. & 734. & 754. & 89 \\
\hline
\end{tabular}

*See article text for explanation of scores derived from Likert scale means.

The statistical results presented in Figure 1 and Table 1 support the conclusion that the belief set and ordering of biblical au thority is wid ely shared and wel 1 co mprehended within the United States. It is su rprising that the CNSS sample responses comprise an item ordering that is closely replicated by a survey of college students. It is further noteworthy that GSS Question 1 encompasses the range of the 11-item scale, with Question 1 responses in the $\mathrm{m}$ iddle, and at both extremes. In order $\mathrm{t}$ o fu rther com pare the two scales we conducte d extensive multivariate estimations of a voter choice model using the full 11-item scale, versus multivariate tests using GSS Question 1 resp onses only, and these estimations are av ailable from the authors upon request. The estimations suggest that both constructs perform in qualitatively similar ways, although the full 11-item construct explains relatively more model d eviance. These multivariate results, tog ether with the scale results, sug gest that GSS 
Question 1 is a valid m easure of bi blical aut hority, a nd that biblical au thority is widely sh ared and well comprehended within the United States across a range of belief sets from conservative Christian to secular.

\subsection{Analysis of Voter Choice}

Hirschl, B ooth and Glenna (2009) a nalyzed dat a from the General Social Survey on voting patterns of white voters in the six presidential elections from 1980 to 2000 . Here we extend their analys is to include the 2004 and 2008 elections, and modify their model to include both regional and time effects.

Table 2. Logistic regression model fits to GSS data concerning presidential voting patterns*

\begin{tabular}{|c|c|c|c|c|c|}
\hline & $980-2000$ & & $1980-2008$ & & \\
\hline HBG & & HBG & $\mathrm{HBG}+\mathrm{R}$ & $\mathrm{HBG}+\mathrm{RE}$ & $\mathrm{HBG}+\mathrm{RE} 3$ \\
\hline Intercept & 0.1100 & .086 & -0.070 & -0.195 & -0.151 \\
\hline $\begin{array}{c}\text { Gender }=\text { female } \\
\text { (male) }\end{array}$ & $-0.348 * * *$ & $0.362 * * *$ & $-0.358 * * *$ & $-0.348 * * *$ & $-0.348 * * *$ \\
\hline $\begin{array}{c}\text { Religion }=\text { Protestant } \\
\text { (Baptist) }\end{array}$ & $-0.037-$ & 0.026 & .053 & 0.026 & 0.012 \\
\hline $\begin{array}{c}\text { Religion }=\text { Catholic } \\
\text { (Baptist) }\end{array}$ & $-0.429 * * *$ & $0.414 * * *$ & $-0.308 * * *$ & $-0.343 * * *$ & $-0.355 * * *$ \\
\hline $\begin{array}{l}\text { Religion }=\text { other } \\
\text { (Baptist) }\end{array}$ & $-1.069 * * *$ & $1.033 * * *$ & $-0.938 * * *$ & $-0.931 * * *$ & $-.929 * * *$ \\
\hline $\begin{array}{l}\text { Biblical Authority } \\
\text { (linear slope) }\end{array}$ & 0.1710 & $.272 * * *$ & $0.258 * * *$ & $0.242 * * *$ & $0.268 * * *$ \\
\hline $\begin{array}{c}\text { Income } \\
\text { (linear slope) }\end{array}$ & $0.218 * * *$ & $0.222 * * *$ & $0.223 * * *$ & $0.234 * * *$ & $0.236 * * *$ \\
\hline $\begin{array}{c}\text { Catholic X biblical } \\
\text { authority }\end{array}$ & $-0.626 * * *$ & $-0.625 * * *$ & $-0.621 * * *$ & $-0.613 * * *$ & $-0.598 * * *$ \\
\hline $\begin{array}{c}\text { Income } \mathrm{X} \text { biblical } \\
\text { authority }\end{array}$ & $0.121 * * *$ & $0.128 * * *$ & $0.129 * * *$ & $0.139 * * *$ & $0.118 * * *$ \\
\hline $\begin{array}{l}\text { Region }=\text { South } \\
\text { (rest of US) }\end{array}$ & -- & -- & $0.231 * * *$ & $0.254 * * *$ & $0.251 * * *$ \\
\hline $\begin{array}{l}\text { Income } \mathrm{X} \text { authority } \\
\mathrm{X} \text { election score }\end{array}$ & -- -- & & -- & -- & $0.039 * * *$ \\
\hline No. Parameters & 99 & & 10 & 17 & 18 \\
\hline$-2 \log \mathrm{L}$ & 10731 & 14513 & 14487 & 14202 & 14152 \\
\hline AIC 1 & 0749 & 14531 & 14507 & 14236 & 14188 \\
\hline $\mathrm{BIC} 1$ & 0812 & 14597 & 14580 & 14360 & 14320 \\
\hline
\end{tabular}

* HB G d enotes m odel 1 fr om Hi rschl, B ooth, \& Glenna (2009); HBG+R de notes the sam e model wi th a indicator for the south added; $\mathrm{HBG}+\mathrm{RE}$ denotes $\mathrm{HBG}$ with an indicator for the south and election year added as a categorical predictor; a nd $\mathrm{HBG}+\mathrm{RE} 3$ includes an additional 3-factor i nteraction between the linea $\mathrm{r}$ term $\mathrm{s}$ for income quartile $(1,2,3$, or 4$)$, Bib lical authority $(-1,0$, or 1$)$ and election score (=(election year-1980)/4). The coefficients for the election years in $\mathrm{m}$ odels $\mathrm{HBG}+\mathrm{RE}$ an $\mathrm{d} \mathrm{HB} \mathrm{G}+\mathrm{RE} 3$ a re $\mathrm{n}$ ot $\mathrm{s}$ hown. Ast erisks denote significance at $\mathrm{p}<0.001 * * *, \mathrm{p}<0.01 * *$, and $\mathrm{p}<0.05 *$.

Table 2 gi ves the results of four different model fits to the 1980-2008 data. ${ }^{2}$ The model denoted by HBG is Model 1 from Hirschl, Booth and Glenna (2009). The model HBG+R contains an additional predictor, a dummy indicator that the voter was from the southern US. Specifically, let $\pi_{i j k l m}$ denote the probability of voting for the Republican candidate (as opposed to the Democratic candidate) for a person of $\operatorname{sex} i$ ( $S$ : $1=$ male, $2=$ male), religious tradition $j$ ( $T: 1=$ B aptist, $2=$ other Protestant, $3=$ Catholic, $4=$ other), in biblical aut hority cat egory $k$ $(1=\mathrm{a}, 2=\mathrm{b}, 3=\mathrm{c})$, income quartile $l$, from region $m(R: 1=$ south, $2=$ not south $)$, then the model is given by 


$$
\ln \frac{\pi_{i j k l m}}{1-\pi_{i j k l m}}=\lambda+\lambda_{i}^{S}+\lambda_{j}^{T}+\beta^{L} L_{k}+\beta^{I} I_{l}+\beta^{L I} L_{k} I_{l}+\beta^{C L} 1_{C} L_{k}+\lambda_{m}^{R},
$$

In model (1) $L$ is a biblical authority score $\left(L_{1}=1, L_{2}=0, L_{3}=-1\right), I$ is an income quartile score $\left(I_{l}=l, l=\right.$ $1,2,3,4)$, and $1_{C}$ is a dummy indicator for Catholics.

The inclusion of a s outhern regional indicator results in a very significant improvement in the fit, reducing the deviance by 26 at the cost of a s ingle parameter. The as sociated coefficient estimate, $0.231(\mathrm{se}=0.045)$ implies that the odds of voting for the republican presidential candidate are a bout $26 \%$ higher among southern whites than tho se in o ther parts of th e co unty, ev en after acco unting fo $\mathrm{r} d$ ifferences i $\mathrm{n}$ i ncome, sex, relig ious denomination and beliefs about biblical authority (a $95 \%$ confidence interval is $15 \%$ to $38 \%$ ).

1st Income Quartile

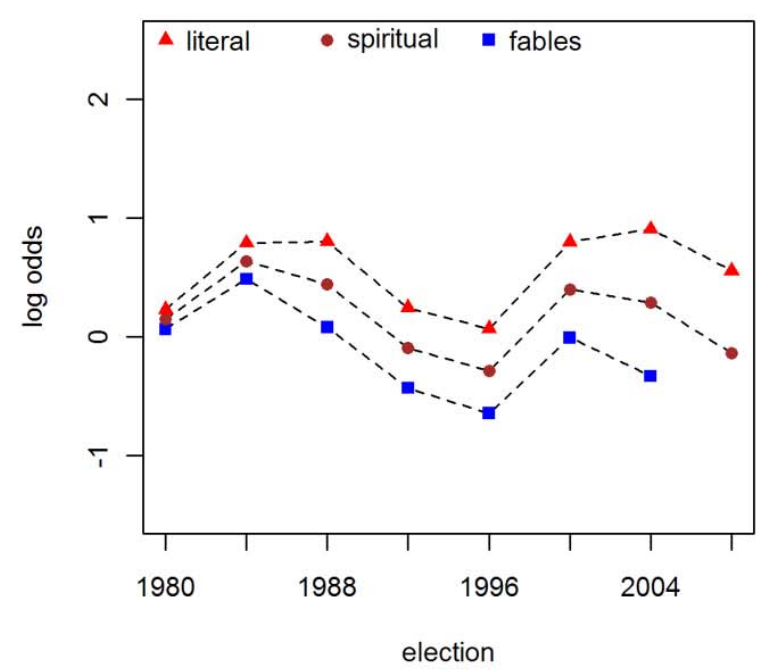

3rd Income Quartile

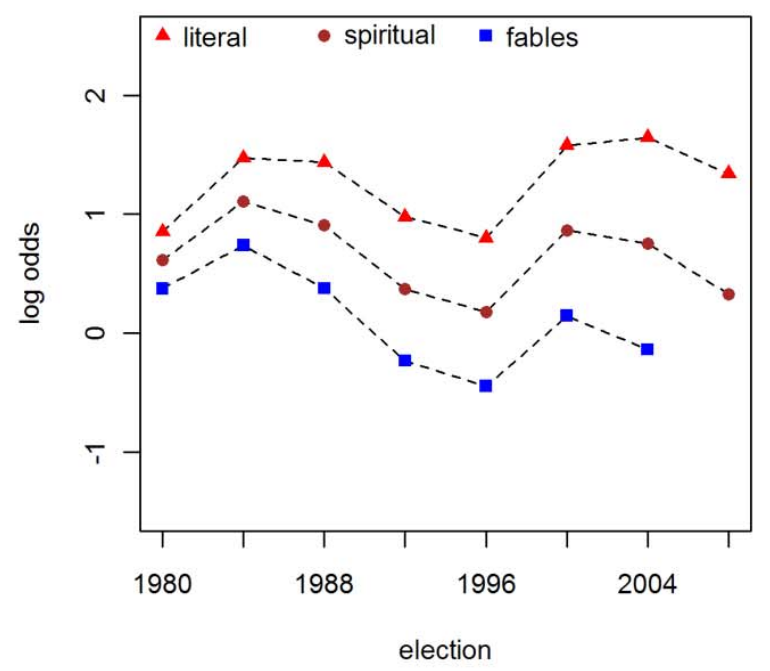

2nd Income Quartile

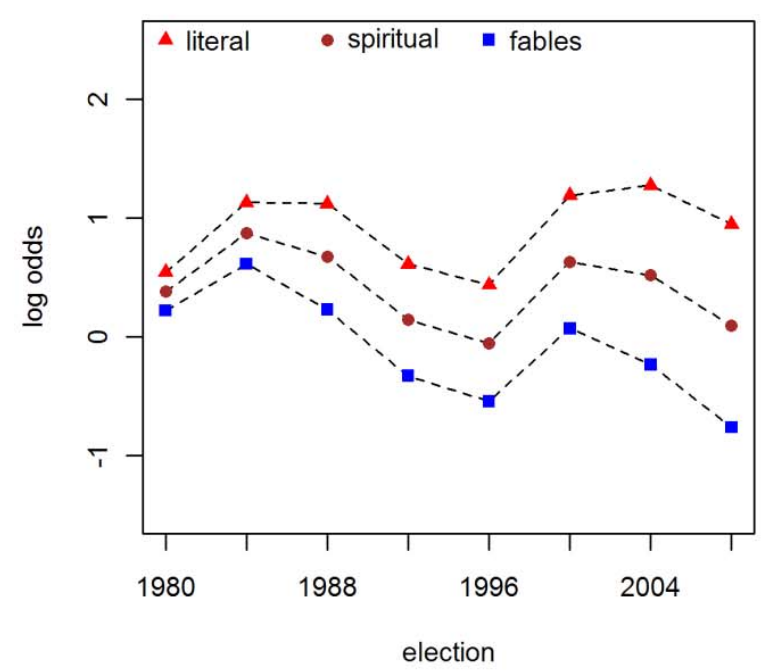

4th Income Quartile

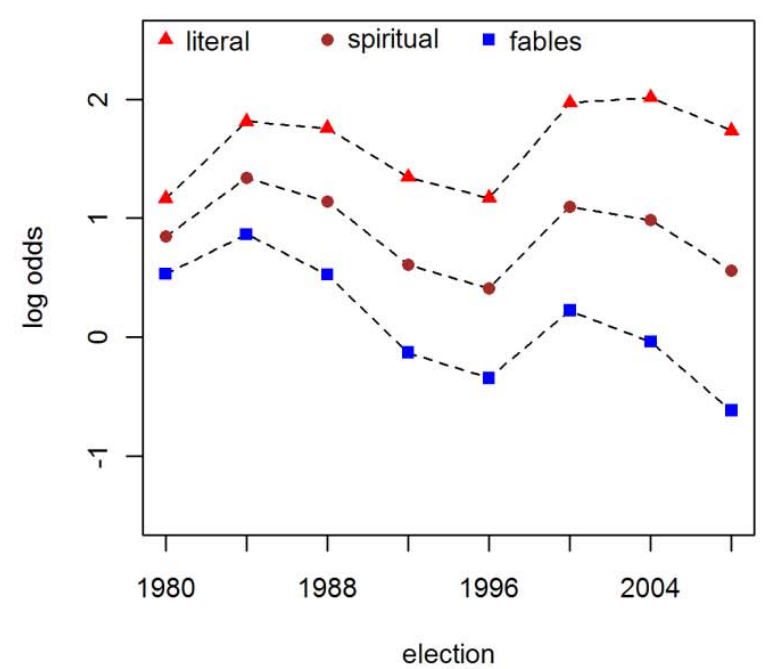

Figure 2. Predicted log odds of voting for the Republican presidential candidate for non-southern, Protestant, white males, as function of time, income quartile and biblical authority response 


\section{1st Income Quartile}

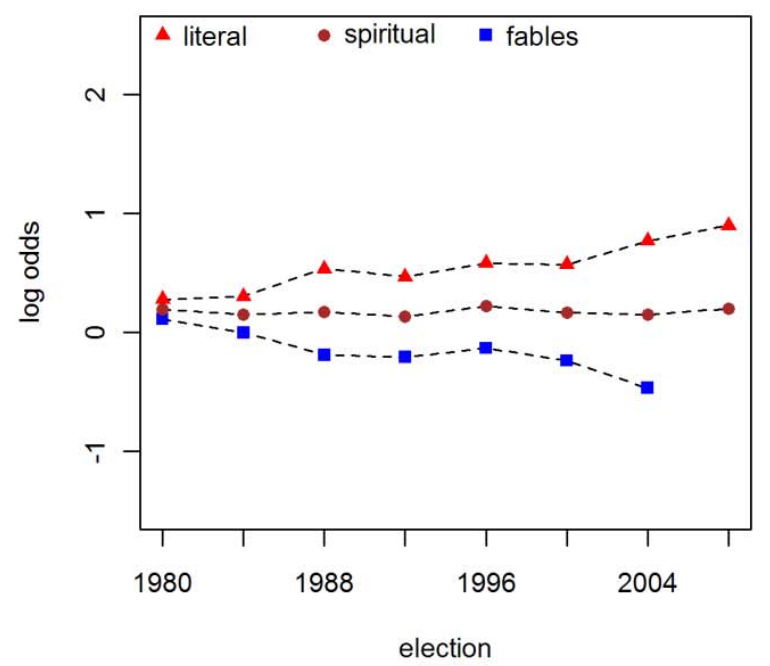

3rd Income Quartile

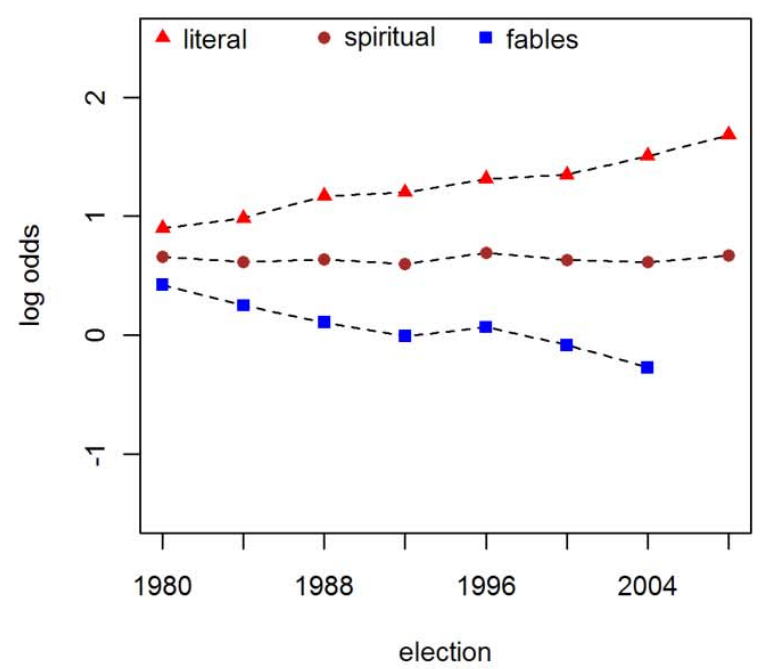

2nd Income Quartile

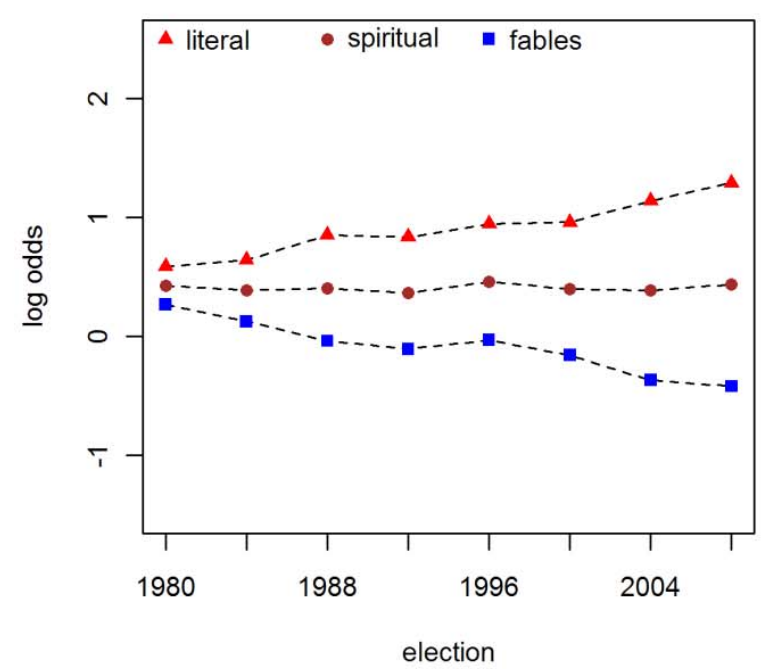

4th Income Quartile

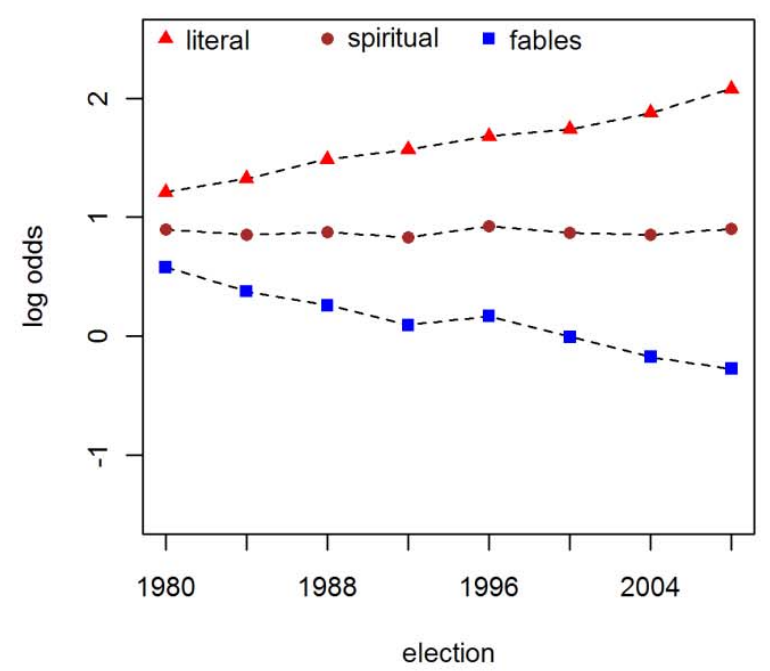

Figure 3. Relative log odds of voting for the Republican presidential candidate for non-southern, Protestant, white males as function of time, income quartile and biblical authority response, after removing the main effect of election. (The main effect of election year has been subtracted out from Figure 2.)

The model HBG+RE includes both the southern regional indicator and election year as a categorical predictor seven d ummy vari ables for el ections 1984-2008, with 1980 being the basel ine cat egory. The i nclusion of election as a predictor res ults in a dram atic improvement in the overall fit with the deviance being reduced by a further 285 points. However, it is interesting to note how the estimated coefficients for the variables in the HBG and $\mathrm{HBG}+\mathrm{R}$ models are relatively unaffected by the inclusion of the election specific effects.

In order to examine the evolution of the $\mathrm{HBG}+\mathrm{R}$ model over time one could fit the model to the data from each election separately and then plot the estimated log odd $\mathrm{s}$ as fun ction of time, controlling for the various model predictors. Th is ap proach is equivalent to including el ection year a s a categorical factor crosse $\mathrm{d}$ wi th every predictor in the $\mathrm{HBG}+\mathrm{R} \mathrm{m}$ odel, therefore multiplying the number of parameters by the number of elections. A more pa rsimonious m odeling a pproach is t o t reat el ection year as a ra ndom factor with a single va riance component ass ociated wi the ach $\mathrm{c}$ rossed factor, a nd hence a fixed $\mathrm{n}$ umber of pa rameters regardless of $\mathrm{the}$ 
number of elections. ${ }^{3}$ This a pproach has the added be nefit of smoothing the predicted log odds by borrowing strength across elections without assuming a particular parametric form for the trends over time.

Figure 2 displays the evolution of predicted $\log$ odds for non-southern, protestant, white, male voters, obtained from the mixed model, for each income quartile, and biblical authority. The figure highlights two points. First, there are large, election year, main effects, which explains the dram atic improvement in fit when election year was added as a predictor to the HBG+R model. For example, the overall tendency to vote Republican was high in 1984, Reagan's reelection year, but low in the 1996, Clinton's reelection year, relative to other election years. Second, the biblical authority groups appear to be diverging over time, with a greater degree of divergence with increasing income. Figure 3 shows the same predicted log od ds with the main effect of election subtracted out, and further suggests that the divergence is approximately linear in time. In modeling terms, the figures suggest there is a three-factor, income $\mathrm{x}$ biblical authority $\mathrm{x}$ time interaction, and that adding a single additional linear $\mathrm{x}$ linear $\mathrm{x}$ linear interaction parameter to the HBG+RE model is sufficient to describe the observed evolution in the $\log$ odds. The resulting model (denoted by HBG+RE3 in Table 2) reduces the deviance a further 50 points, and is preferred over all other models considered in terms of the AIC and BIC model selection criteria.

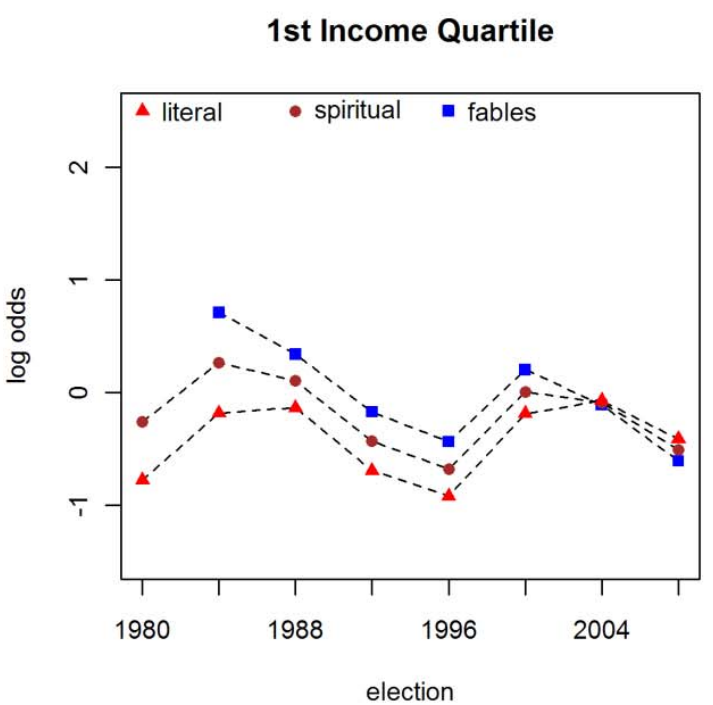

3rd Income Quartile

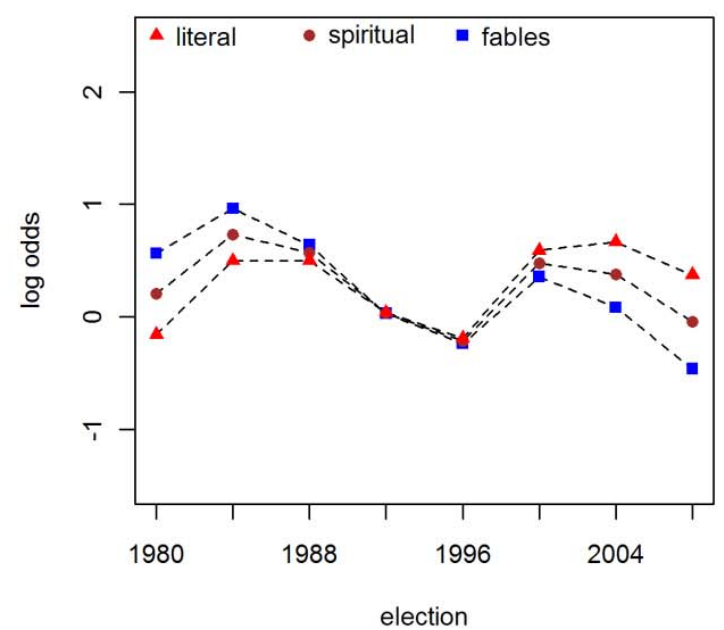

2nd Income Quartile

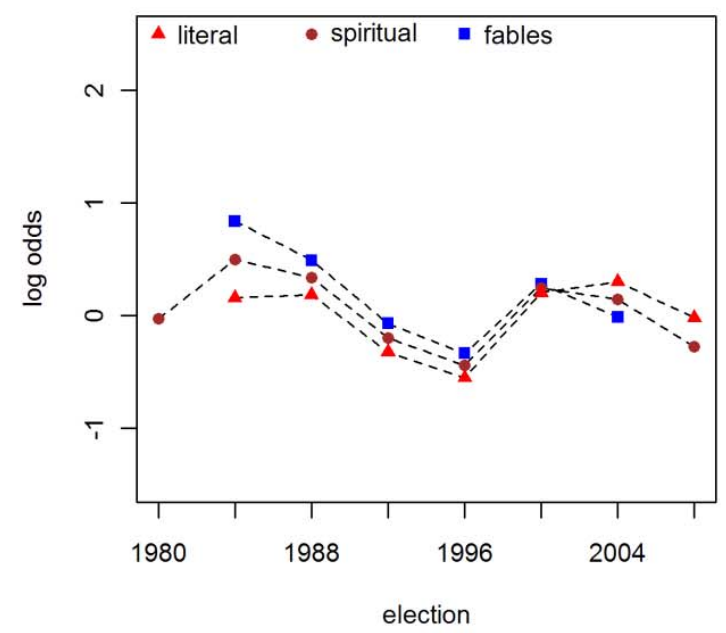

4th Income Quartile

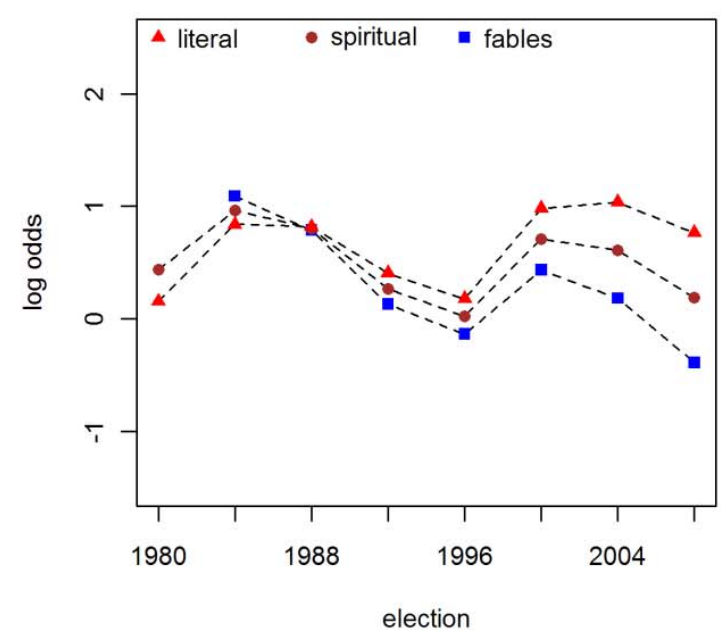

Figure 4. Predicted log odds of voting for the Republican presidential candidate for non-southern, Catholic, white males as function of time, income quartile and biblical authority response 
1st Income Quartile

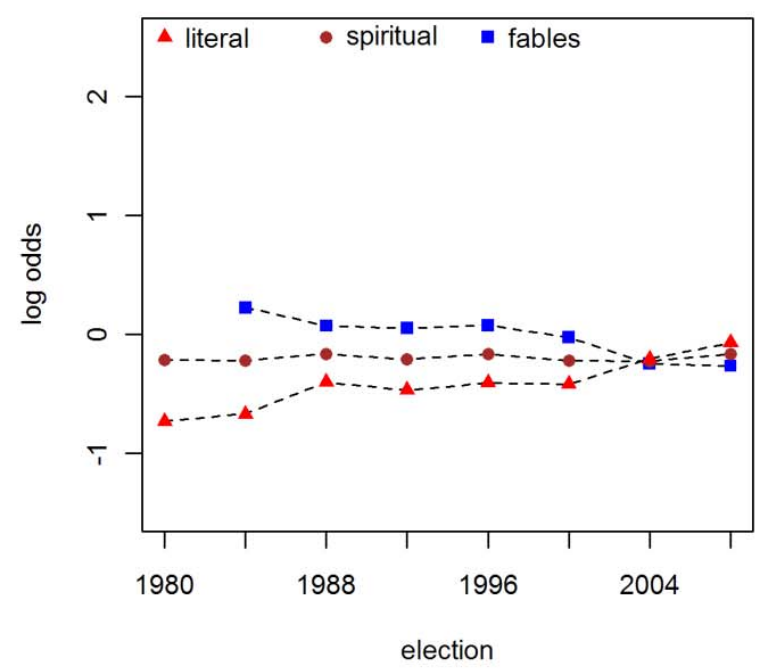

3rd Income Quartile

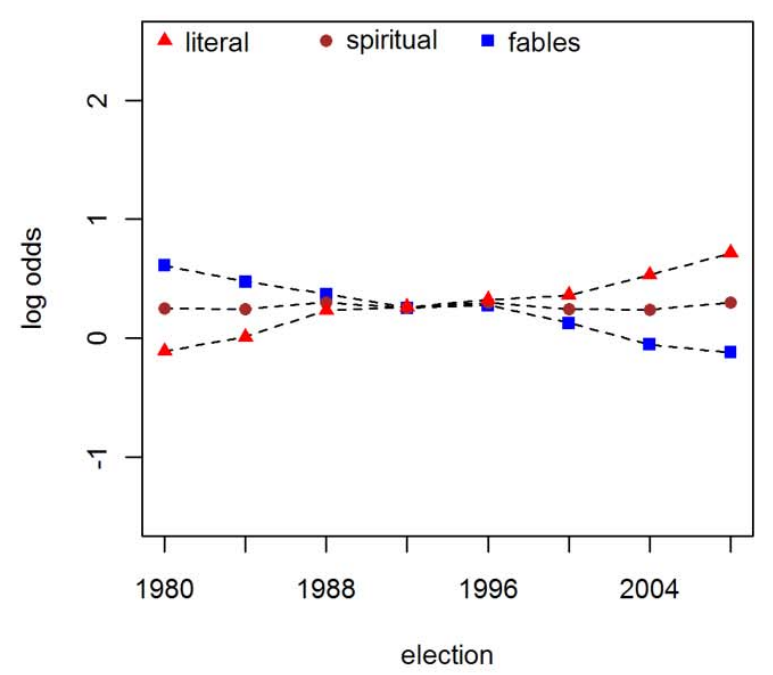

2nd Income Quartile

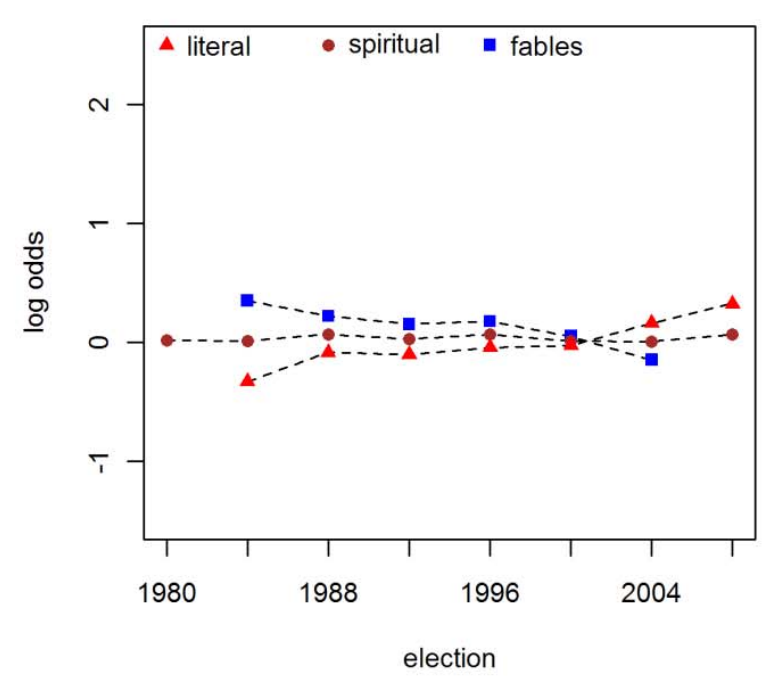

4th Income Quartile

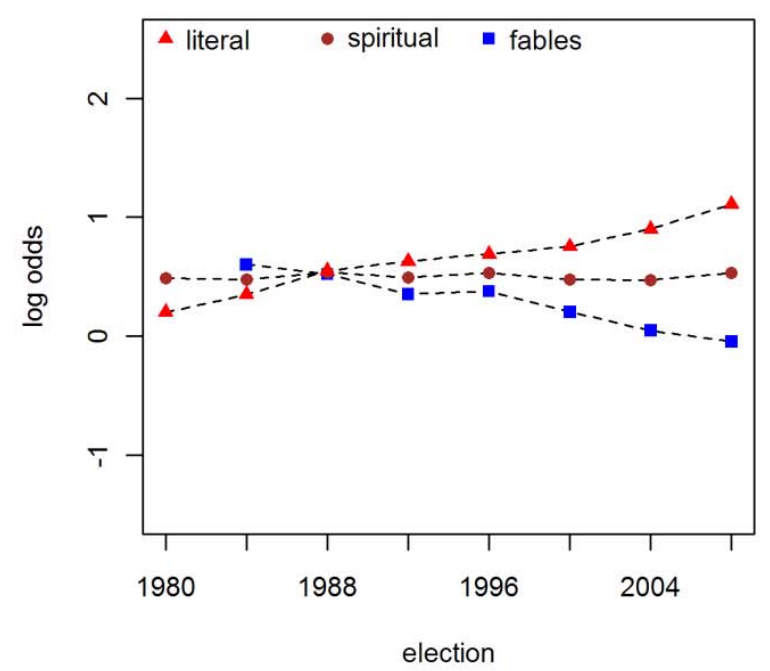

Figure 5. Relative log odds of voting for the Republican presidential candidate for non-southern, Catholic, white males as a function of time, income quartile and biblical authority response, after removing the main effect of election (The main effect of election year has been subtracted out from Figure 4.)

Figures 4 and 5 give the a nalogous pl ots for the white, non-southern, $\mathrm{C}$ atholics. These plots show si milar election year main effect patterns, and an overall tenden cy for Catho lics to b e less Repub lican th an th eir Protestant counterparts. A striking difference between Catholics and Protestan ts is th at the association between voting Republican and biblical authority in the 1980 election is in the opposite direction, with Catholic biblical literalists being the least likely Republican voters. However, the three-factor interaction noted in Figures 2 and 3 is al so present am ong Catholics so t hat, over time, the direction of the association reverses, with the reversal occurring earlier as income increases.

Similar analysis of black voting pattern s does not reveal any noticeable time trends with res pect to biblical authority or famil y in come. Black voters overwhelmingly favored the Democratic candidate in all Presid ential elections from 1980 to 2008, with the only statistically significant factors being sex (black women are even less Republican than black men) and region (southern blacks are slightly more likely to vote Republican). 


\section{Discussion and Conclusion}

This paper set out to $\mathrm{m}$ easure the trend line in religious political polarization with in the United States, and to determine the extent that polarization, if any is fo und, is more pronounced with in the upper, versus the lower, reaches of the stratification order. Prior research is divided on the trend in religious political polarization sinc e 1980, with some stu dies indicating no polarization, and other studies finding positive evidence. In addition there have been attempts to link religious political behavior to the politics of inequality, but these attempts generally lack firm em pirical grounding, and have been judged to be unconvincing. The empirical anal ysis models the effect of relig ious id entity on Presiden tial voter ch oice across the so cial class $\mathrm{h}$ ierarchy (measured as relative family income), the race hierarchy, and the gender hierarchy. We reason that the stratification pattern of religious political polarization constitutes an empirical footing for interpreting the link between social inequality, religion, and political behavior.

The first analytical task is validating the measurement of religious identity, a necessary step given differences in the literature between the two most common measurement ap proaches. Our chosen measure is rel ated to both approaches, ye $t$ also distinct in sofar as it focuses upon bib lical authority. The fo cus o $\mathrm{n}$ b iblical authority is justified by the Bib le's p resence within secu lar as well as relig ious realms of American society, potentially entering into symbolic preferences regarding how society should best be governed.

To assess the degree that biblical belief constitutes a valid concept for measuring religious identity, two surveys were undertaken. First, a nationally representative sample asked a set of five questions concerning biblical belief in relation to politics, personal decision-making, and social morality. Included within the five questions was the General Social Survey question ab out biblical au thority, and it was found that responses to the five questions form a single-dim ension scale with sec ular responses at one pole, religious responses at the opposite pole, and these two poles connected by a set of progressively religious/secular states. The second survey tested the biblical belief scale by asking a set of college students to rank the scale items, and the results confirmed the rankings. All of this suggests that people are well versed ab out biblical authority and social conduct, and assign a common ordering across a progressively religious/secular set of states.

The multivariate analysis of religious identity effects on voter choice invites the following interpretations. First, that religious identity was an influence on voter choice during the period 1980 to 2008 where individuals stating that the Bible is the literal word of God were stron gly inclined to vote Republican, versus secular individuals believing $t$ hat $t$ he B ible i s a bo ok of fables v oting strongly Dem ocratic. Sec ond, that effect increase $\mathrm{d}$ significantly across the study period, consistent with research finding religious political polarization during the same $t$ ime $p$ eriod. Th ird, that relig ious i dentity lin ked to $p$ artisan polarity is co ncentrated with in the up per reaches of the stratification order defi ned by upper inc ome whites. There is no discernable effect of religious identity on voter cho ice amo ng blacks who were stron g De mocratic vo ters acro ss all categ ories of relig ious identity. This finding is consistent with the long-term trend in African-American partisanship that began shifting toward the De mocrats fo llowing the 1932 electio n of Franklin R oosevelt; b efore then blacks were stro ng Republicans, the party sy mbolizing an ti-slavery. Pr ior to 19 32, D emocrats were pe rceived by many African Americans to be implicated in racism and in supporting the Confederacy. Conversely whites, the dominant racial group, are sh arply divided by religious identity, in particular within the upper levels of the income distribution. The effect of gender on partisanship is less pronounced, and overshadowed by social class and religious identity. Thus for example, al though women in the aggregate are net Democratic partisans, upper class, white, biblical literalist, Protestant women are strong Republican partisans.

The trend line in Protestant partisanship between 1980 and 2008 suggests growing religious-political polarization, where liberal interpreters of biblical authority became stronger Democratic partisans, and literal inte rpreters of biblical authority beca me stronger Republican voters. This polarization trend was in tra-class salient within the upper income quartile, while diffusing down ward over time to the lower reaches of the social class h ierarchy. The time trend suggests that religious identity di vides upper class Protestants, and this upper class divide has more o r less faint reflections within the lower cla sses. Thu s religious political po larization amo ng wh ite Protestants is characterized by intra-class polarity, and not inter-class polarity.

The tr end lin e in Catho lic partisanship is t he same as the Pr otestant tren d, althoug h less Repub lican overall. Between 1980 and 2008, bibli cal literalist Catholics became stronger Republican voters, and liberal interpreters of biblical authority became stronger Democratic vote rs, with polarization between these two groups greatest within the top income quartile. Thus the trend in Catholic partisanship relative to income and biblical belief is the same as Protestant trend. When considering the Protestant and Catholic trend together, it suggests a common underlying trend in religiously linked, political partisanship. 
In so me respects the study findings confirm the two dom inant theories of relig ion and politics. The pattern of Protestant and Catholics partisanship is consistent with the eth noreligious proposition that these two traditions evolved different partisan political linkages over time. Protestant partisanship is relatively less divided by social class, and more divided by biblical belief in comparison to Catholic partisanship that is more divided by social class, and less $d$ ivided by biblical b elief. We speculate that th is difference is related to how po litical parties appeal to these two religious traditions, as well as to religious differences in theology and church organization. The data are consistent with an historical 1 ink bet ween $\mathrm{C}$ atholicism and $\mathrm{t}$ he Dem ocrat Pa rty em phasizing working class po pulism, an $\mathrm{d}$ a $\mathrm{m}$ oral imp erative to redistribute to the lower classes. Th e link b etween Protestantism and the Republican Party presents little or no evidence for working class populism.

The study resu lts are so mewhat con sistent with religious restructuring t heory. $\mathrm{C}$ atholics a nd $\mathrm{P}$ rotestants polarized on the basi s of biblical bel ief where 1 iberal interpreters increasing ly fa vored the Democrats, and Republican partisanship strengthened among literal interp reters. Indeed, the fi nding of a positive tim e trend in partisan polarization related to trans-tradition religious identity is the epitome of religious restructuring theory. A limitation of religious rest ructuring the ory, howe ver, becomes appare nt with regard to race. Bl ack voters remained stron $g$ Democratic $\mathrm{p}$ artisans acro ss th e st udy peri od, sh owing no i nclination t o polarize aro und religious identity.

The theoretical framework of this study provides an alternative interpretation to the ethnoreligious view of race. Ethnoreligious resea rchers $\mathrm{c}$ lassify ch urches with predominately bl ack congregations sepa rately from whi te congregations, and the orize that the link between black churches and the Democratic Party is a function of race and historical experience. From our perspective, however, the experience of race is to some degree independent of religion, and th e link $b$ etween race and political $p$ artisanship is th eorized as an outcome o $f$ domination/subordination within the stratification ord er. Religious id entity e mpirically functions as a $\mathrm{p}$ artisan influence for the dominant race, but not for the sub-dominant $\mathrm{r}$ ace, that votes a s a block. This perspective resonates with $\mathrm{Du}$ rkheim's so cial view of religion set fo rth i $\mathrm{n}$ The Elementary Forms wh ere religious consciousness reflects and reinforces social and economic relationships.

The study findings suggest that the in fluence of religious identity on Presidential voter choice is st rengthening during a period of rising eco nomic in equality. Th is influence is co ncentrated within upp er class whites, and therefore not consistent $\mathrm{w}$ ith the term "culture war" because war i mplies that all of s ociety is enga ged. Secular/religious political polarization over the period 1980 - 2008 in the United States reflects division within upper class whites, and is not a society wide phenomenon. Furthermore, this division affords an opportunity for the major political parties, and their candidates, to market themselves religiously without entertaining concrete economic policies that might atten uate economic in equality. In this sen se we con cur that relig ious po litics are extraneous to the politics of economic inequality. Political activity aimed at reducing economic inequality would be strategically served by dialogue with the lower classes that are, in fact, the economic polarization losers, and therefore have the most to gain.

The U.S. e vidence s uggests that seculariza tion predicted by earlier s ocial scien tists is $p$ remature at best, and perhaps altogether misplaced. Religious worldviews continue to play an active role in U.S. Presidential politics, and there is no evidence that this role will diminish in the short-term, or in the medium term. We believe that a fruitful theory for interpreting these phenomena is Dur kheim's theory set forth in The Elementary Forms. The empirical link between religion and politics suggests that religion in the United States is not confined to formal institutions, but also is an element in constituting the national community.

\section{Acknowledgements}

The Cornell University Experiment Station, Hatch Grant 159-6453, provided support for this research.

\section{References}

Atkinson, A. B., Piketty, T., \& Saez, E. (20 11). Top Incomes in the Long Run of History. Journal of Economic Literature, 49, 3-71.

Bartels, L. M. (2005). What's the Matter with What's the Matter with Kansas?. Paper prepared for presentation at the a nnual $\mathrm{m}$ eetings of the American Poli tical Sc ience Ass ociation, Was hington, DC, Sept ember 1- 4. Retrieved from http://www.princeton.edu/ bartels/kansas.pdf.

Billings, D. B., \& Scott, S. L. (1994). Rel igion and Political Leg itimation. Annual Review of Sociology, 20, 173-202.

Bolce, L., \& DeMaio, G. (1999). The Anti-Christian Fundamentalist Factor in Contemporary Politics. The Public Opinion Quarterly, 63, 508-542. 
Brooks, C., \& Man za, J. (2 004). A Great Di vide: Relig ion and Po litical Ch ange in U.S. National Electio ns, 1972-2000. The Sociological Quarterly, 45, 421-450.

Converse, P. E. (1964). The N ature of B elief Sy stems in Mass Publics. In D. E . Apter (ed.), Ideology and Discontent (pp. 206-261). New York: Free Press of Glencoe.

Davis, J. A., Smith, T. W., \& Marsden, P. V. (2005). General Social Surveys, 1972-2004 [Cumulative File]. Ann Arbor, M I: In ter-university Co nsortium fo $r$ Po litical an d So cial Research . Retriev ed fro $m$ http://webapp.icpsr.umich.edu/cocoon/ICPSR-SERIES/00028.xml.

Domhoff, G. W. (2002). Who Rules America? Power and Politics (4th ed.). Boston : McGraw Hill.

Durkheim, E. (2001). The Elementary Forms of Religious Life. New York: Oxford University Press.

Fiorina, M. P., Abrams S. J., \& Pope, J. C. (2011). Culture War? The Myth of a Polarized America. Boston, MA: Longman.

Frank, T. (2004). What's the Matter with Kansas? How Conservatives Won the Heart of America. New Y ork: Henry Holt and Company.

Gelman, A., Park, D, S hor, B., \& Cortina, J. (2010). Red State, Blue State, Rich State, Poor State: Why Americans Vote the Way They Do (expanded paperback edition). Princeton University Press: Princeton, NJ.

Greeley, A., \& Hout, M. (2006). The Truth About Conservative Christians. Chicago: The University of Chicago Press.

Greenacre, M., \& Blasius, J. (2006). Multiple Correspondence Analysis and Related Methods. Boca Raton, LA: Chapman \& Hall/CRC.

Guth, J. L., Kellstedt, L. A., Smidt, C. E., \& Green, J. C. (2 006). Religious Influences in the 2004 Presidential Election. Presidential Studies Quarterly, 36, 223-242.

Hacker, J. S., \& Pierso n, P. (201 0). W inner-Take-All Politics: Public Po licy, Po litical Org anization, an d the Precipitous Rise of Top Incomes in the United States. Politics \& Society, 38, 152-204.

Hirschl, T. A., Booth, J. G., \& Glen na, L. L. (2009). The Link Between Voter Choice and Religious Identity in Contemporary Society: Bringing Classical Theory Back In. Social Science Quarterly, 90, 927-944.

Hunter, J. D. (1991). Culture Wars: The Struggle to Define America. New York: Basic Books.

Inglehart, R., \& Baker, W. E. (2000). Looking Forward, Looking Back: Continuity and Change at the Turn of the Millennium. American Sociological Review, 65, 19-51.

Jensen, R. J. (1971). The Winning of the Midwest: Social and Political Conflict, 1988-96. Chicago: University of Chicago Press.

Kleppner, P. (1979). The Third Electoral System: Parties, Voters and Political Cultures. Chapel Hill: University of North Carolina Press.

Knoke, D. (197 4). Religion, Stratification and Politics: American in the 1960s. American Journal of Political Science, 18, 331-345.

Kramnick, I., \& Moore, R. L. (2005). The Godless Constitution: A Moral Defense of the Secular State. New York: W.W. Norton.

Kuznets, S. (1955). Economic Growth and Income Inequality. American Economic Review, 45, 1-28.

Layman, G. (2001). The Great Divide: Religious and Cultural Conflict in American Party Politics. New York: Columbia University Press.

Layman, G. C. (1997). Religion and Political Behavior in the United States: The Impact of Beliefs, Affiliations, and Commitment from 1980 to 1994. The Public Opinion Quarterly, 61, 288-316.

Manza, J., \& Brooks, C. (1997). The Religious Factor in U.S. Presidential Elections, 1960-1992. The American Journal of Sociology, 103, 38-81.

Perrucci, R., \& Wysong, E. (2007). The New Class Society (3rd ed.). Lanham, Md: Rowman \& Littlefield.

Phillips, K. (2006). American Theocracy: The Peril and Politics of Radical Religion, Oil, and Borrowed Money in the $21^{\text {st }}$ Century. New York: Viking.

R Development Core Team. (2010). R: A Language and Environment for Statistical Computing. R Foundation for Statistical Computing, Vienna, Austria. Retrieved from http://www.R-project.org 
Regenerus, M. D., Sikkink, D., \& Smith, C. (1999). Voting and the Christian Right: Contextual and Individual Patterns of Electoral Influence. Social Forces, 77, 1375-1401.

Riesebrodt, M. (1993). Pious Passion: The Emergence of Modern Fundamentalism in the United States and Iran. Berkeley: University of California Press.

Sherkat, D. E., \& Ellison, C. G. (1999). Recent Developments and Current Controversies in the Sociology of Religion. Annual Review of Sociology, 25, 363-394.

Steensland, B., Park, J. Z., Regnerus, M. D., Robinson, L. D., Wilcox, W. D., \& Woodberry, R.D. (2000). The Measure of American Religion: Toward Improving the State of the Art. Social Forces, 79, 291-318.

U.S. Census Bureau. (2011). Current Population Survey, Annual Social and Economic Supplements. Retrieved from http://www.census.gov/hhes/www/income/data/historical/inequality/index.html.

Weber, M. (2004). The Essential Weber: A Reader, edited by Sam Whimster. New York: Routledge.

Weber, M. (1958). The Protestant Ethic and the Spirit of Capitalism. New York: Charles Scribner's Sons.

Williams, R. H. (1997). Culture Wars in American Politics: Critical Reviews of a Popular Myth. New York: Aldine de Gruyter.

Wolff, E. N. (2010). Recent Trends in Household Wealth in the United States: Rising Debt and the Middle-Class Squeeze--an Update to 2007. Annandale-on-Hudson, NY: Le vy Ec onomics Institute. Retrie ved from http://www.levyinstitute.org/publications/?docid=1235,

Woodberry, R. D., \& Smith, C. S. (1998). Fundamentalism Et Al: Conservative Protestants in America. Annual Review of Sociology, 24, 25-56.

Wright, E. O . ( 1996). T he Continuing R elevance of C lass A nalysis - C omments. Theory and Society, 25, 693-716.

Wuthnow, R. (1988). The Restructuring of American Religion. Princeton, NJ: Princeton University Press.

\section{Notes}

Note 1 . These averages are based on 108 students who gave logically coherent sc ores. F or example, students who assigned a score of 1 to every response were eliminated.

Note 2. A caveat $\mathrm{h}$ ere is th at these statistic al tests a ssume random sampling, whereas in fact the survey uses probability sampling. The tests do not account for differences in sampling weights among individual respondents. The GSS provid es wei ghts for over-sampling of racial minorities and o ther demographic groups. Since our analysis is conducted separately for racial sub-samples, we maintain that these weights are unlikely to affect our conclusions.

Note 3. The model fitting was accomplished using the lme4 package in R (R Development Core Team, 2010). 